This is an Open Access article distributed under the terms of the Creative Commons Attribution 4.0 International License which permits unrestricted non-commercial use, distribution, and reproduction in any medium, provided the original work is properly cited.

http://ijnms.net/index.php/ijnms

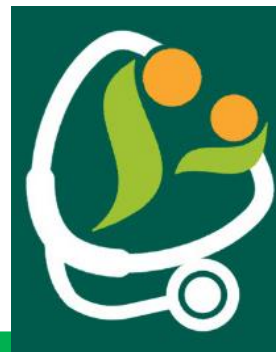

\title{
HYPNOTHERAPY DECREASES STRESS IN ELDERLY HYPERTENSION
}

Kastubi *, Minarti**, Noer Saudah***

*Nursing Study Program of Poltekkes Kemenkes Surabaya

**Nursing Study Program of Poltekkes Kemenkes Surabaya

****Maternity of Nursing STIKES BINA SEHAT PPNI

\section{ABSTRACT}

Keywords

Stress stimulates the sympathetic nervous encouraging the heart and cause an increased blood pressure. Efforts to reduce hypertension pharmacological and non-pharmacological. The non-pharmacological experiment of which is hypnosis. The research objective was to analyze the decrease of stress in elderly hypertensive therapy with hypnotherapy.

The research design used experimental pretest - Posttest with Control Group. The population was all the elderly with hypertension in the elderly health care center PacarKeling, and Kemayoran Surabaya with 35 elderlies. Some sample 15 intervention group, 15 control group. The sampling technique used Simple Random Sampling. The variable intervention was therapeutic applications of hypnosis to elderly hypertensive. The dependent variable was the stress in elderly hypertensive. The statistical test used paired t-test. It showed changes in stress to the control group -7.33, while the experiment group amounted to 14.60. Results can reduce stress in the group treated with hypnotherapy an average decrease of 14.6. Results showed that there were differences in the level of stress control and experiment groups with a significant value of $p=0.000(p<0.05)$, The effect of hypnotherapy was shown in the systolic blood pressure change between control and experiment groups showed a mean difference of ranks. In the control group 20.8, while in the experimental group 10.2. Mann Whitney test results obtained by the significant value of $p=0.000(p<0.05)$ in mean systolic blood pressure differences between control and experiment groups. Hypnotherapy can reduce stress and blood pressure in the experiment group. Causes of stress on the individual such as physical pain and the outside factor could be due to family problems, economic. Suggestions that hypnosis can be used as a new experimental method stress problem in the elderly 


\section{INTRODUCTION}

Hypertension is a disease ranks to five (5) of the diseases that cause death in the world and opens 12 times greater risk for sufferers of stroke, six times greater for a heart attack, and five times more likely to die of heart failure ( Sustrans; Natural \&Hadibroto, 2004). The incidence of hypertension in Indonesia identified five times more compared with developed countries (Wiryanto, 2004). Based on preliminary data in health care center of elderly in the village of Pacarkeling found that of 10 elderly hypertensives stressed by seven people $(70 \%)$. Given the harmful effects of stress, then the management of stress needs to be done, particularly in individuals with hypertension. Stress management is so that people who are under stress can control themselves when experiencing situations or events that require higher demands on the capabilities.

Hypertension itself due to many factors including genetic factors, obesity, stress, excessive salt intake, smoking, alcohol, and hormones that affect blood pressure such as renin-angiotensin-aldosterone, saturated fatty acids and high cholesterol in the blood. Various strategies can be done in reducing hypertension to elderly as a low-salt diet, exercise, medication both pharmacological and non-pharmacological. The nonpharmacological experiment includes deep relaxation using hypnosis, time management, positive thinking, able to adapt to change, to laugh, to express feelings. Hypnosis by Gunawan (2010) is a condition in which attention becomes very centrally so that levels rise very high suggestibility. Hypnosis is the art of communication to influence someone to change the level of awareness, which is achieved by lowering the brain waves and artistic exploration of the unconscious. According to Kusuma (2002), stating that hypnosis therapy can cure diseases such as asthma, sinusitis, arthritis, seasickness, menstrual disorders, high blood pressure, stroke, impotence, and pain management.

Based on the above formulation of the problem was whether hypnosis reduces stress in elderly hypertensive health care center in Surabaya? The research objective was to analyze the decrease in stress in elderly hypertensive therapy with hypnosis.

\section{MATERIALS AND METHODS}

This research uses experimental design pretest - Posttest with Control Group

\begin{tabular}{llc}
\hline & $\begin{array}{l}\text { Pre-test } \\
\text { post-test }\end{array}$ & experiment \\
\hline $\begin{array}{l}\text { Experiment } \\
\text { group }\end{array}$ & $01 \mathrm{a}$ & $\mathrm{Xa}$ \\
& $02 \mathrm{a}$ & \\
\hline Control group & $01 \mathrm{~b}$ & \\
& $02 \mathrm{~b}$ & \\
& & \\
\hline
\end{tabular}

The study population was all elderly with hypertension in the elderly health care center PacarKeling and Kemayoran Surabaya 35 elderly. Criteria population was elderly (start pre-senile to seniors) were 50-80 years old, and can communicate well, do not have a hearing loss. Samples were some of the elderly population with hypertension in the elderly health care center of Kemayoran and Pacarkeling Surabaya. The sample of the research was 15 votes for the intervention group and 15 to the control group.

Simple random sampling did sampling. Simple random sampling is that each member or unit of the population has an equal chance to be 
selected as the sample (Notoatmodjo, S, 2005). Collecting data in this research used a questionnaire to measure stress elderly, observation by measuring the blood pressure of elderly and identify any changes in elderly hypertensive level after an intervention. The research variable consisted of an intervention variable was therapeutic applications of hypnosis research conducted in the elderly with hypertension and the dependent variable was the stress to elderly hypertensive. Operational definitions of variables intervention therapeutic applications of hypnosis where the application of hypnosis therapy given in elderly hypertensive. The dependent variable stress in elderly hypertensive is feeling distressed experienced by the elderly at the 50-80 years old pre-senile to seniors who suffer an increase in blood pressure of $>140 / 90 \mathrm{mmHg}$. Analysis of the data in the study was the unvaried analysis, in the form of a frequency distribution and percentage of each variable. The statistical test used in the bivariate analysis using pair t-test with a significance level of $95 \%$ (alpha 0.05 ).

\section{RESULTS}

The research was conducted in two (2) elderly health care center, namely; (1) health care center of Kemayoran Kembangan South Surabaya, and (2) Elderly mobile health care center of Pacar Keling Kembangan village. The two elderly health care center always actively carry out routine activities every month, Healthcare center activities included; gymnastics elderly, teaching, health screening, and health education. In the implementation, accompanied by officials from the health center. In addition to a health worker of an elderly health center, Kemayoran Surabaya is used as the target area Sutopo Nursing Study Program of Polytechnic Health "Kemenkes," Surabaya. The number of elderly in this research used 15 elderly hypertensives, elderly health care center of "RW" 10 of PacarKeling, Kembang village, used as the intervention group and 15 elderly hypertensives of health care center Kemayoran, used as a control group. The total number of elderly used in this study were 30 respondents.

\subsection{Information Secondary Data}

In addition to general data were also obtained data relating to the regularity of the elderly in taking medication and whether there was a genetic component in both groups. The results can be seen in the following table:

\section{Table1.}

Frequency Distribution of Drinking Drug Regularity in the control and experiment

\begin{tabular}{cccc}
\hline \multirow{2}{*}{$\begin{array}{c}\text { Taking } \\
\text { medication }\end{array}$} & \multicolumn{2}{c}{ Group } & Total \\
\cline { 2 - 4 } & control & experiment \\
\hline regular & 4 & 15 & 19 \\
\cline { 2 - 4 } & $21.1 \%$ & $78.9 \%$ & $100.0 \%$ \\
\hline \multirow{2}{*}{ Not regular } & 11 & 0 & 11 \\
\cline { 2 - 4 } & $100.0 \%$ & $0 \%$ & $100.0 \%$ \\
\hline \multirow{2}{*}{ Total } & 15 & 15 & 30 \\
\cline { 2 - 4 } & $50.0 \%$ & $50.0 \%$ & $100.0 \%$ \\
\hline
\end{tabular}

Table 1. it showed that in the control group who regularly take medication there are four people in the experiment group, while there were 15 people. 
Table2.

Frequency Distribution Descendants in the control and experiment

\begin{tabular}{cccc}
\hline \multirow{2}{*}{ Ancestry } & \multicolumn{2}{c}{ Group } & Total \\
\cline { 2 - 4 } & Control & experiment \\
\hline \multirow{2}{*}{ Nothing } & 10 & 10 & 20 \\
\cline { 2 - 4 } & $50.0 \%$ & $50.0 \%$ & $100.0 \%$ \\
\hline \multirow{2}{*}{ parent } & 5 & 5 & 10 \\
\cline { 2 - 4 } & $50.0 \%$ & $50.0 \%$ & $100.0 \%$ \\
\hline \multirow{2}{*}{ Total } & 15 & 15 & 30 \\
\cline { 2 - 4 } & $50.0 \%$ & $50.0 \%$ & $100.0 \%$ \\
\hline
\end{tabular}

Table 2 shows that genetic factors in both groups. In the control group and the same experiment - both have offspring disease, five people.

To ensure that the frequency distribution of offspring between the two groups of homogene chi-square test. The results is showed of chi-square test significance value 1,000. The significance value greater than $p=0.05$ then there is no significant difference between the proportion factor hereditary disease experiment and control groups. Or in other words, the data are homogeneous heredity. Normality test data used is Kolmogorov Smirnov. Data is said to be normally distributed if its significance is more than $\mathrm{p}=$ $0: 05$. The test results of normality can be seen in the following table:
Table 3

Normality Test on Research Data (Stress, systolic and diastolic) in the control and experiment groups

\begin{tabular}{|c|c|c|c|c|c|c|}
\hline \multirow[b]{2}{*}{ Data } & \multicolumn{3}{|c|}{ control } & \multicolumn{3}{|c|}{ experiment } \\
\hline & Sig. & $\begin{array}{l}\text { Stan } \\
\text { dard }\end{array}$ & $\begin{array}{c}\text { stat } \\
\text { us }\end{array}$ & $\begin{array}{l}\mathrm{Si} \\
\text { g. }\end{array}$ & $\begin{array}{l}\text { Stan } \\
\text { dard }\end{array}$ & $\begin{array}{c}\text { statu } \\
\mathbf{s}\end{array}$ \\
\hline Stress pre & 0.399 & $\begin{array}{c}> \\
0.05\end{array}$ & $\begin{array}{l}\text { Nor } \\
\text { mal }\end{array}$ & $\begin{array}{c}0.5 \\
53\end{array}$ & $\begin{array}{c}> \\
0.05\end{array}$ & $\begin{array}{l}\text { Nor } \\
\text { mal }\end{array}$ \\
\hline Stress post & 0.310 & $\begin{array}{c}> \\
0.05\end{array}$ & $\begin{array}{l}\text { Nor } \\
\text { mal }\end{array}$ & $\begin{array}{l}0.6 \\
61\end{array}$ & $\begin{array}{c}> \\
0.05\end{array}$ & $\begin{array}{l}\text { Nor } \\
\text { mal }\end{array}$ \\
\hline $\begin{array}{c}\text { difference } \\
\text { stress pre } \\
\text { and post }\end{array}$ & 0.660 & $\begin{array}{c}> \\
0.05\end{array}$ & $\begin{array}{l}\text { Nor } \\
\text { mal }\end{array}$ & $\begin{array}{l}0.4 \\
83\end{array}$ & $\begin{array}{c}> \\
0.05\end{array}$ & $\begin{array}{l}\text { Nor } \\
\text { mal }\end{array}$ \\
\hline Systole pre & 0.269 & $\begin{array}{c}> \\
0.05\end{array}$ & $\begin{array}{l}\text { Nor } \\
\text { mal }\end{array}$ & $\begin{array}{l}0.1 \\
32 \\
\end{array}$ & $\begin{array}{c}> \\
0.05\end{array}$ & $\begin{array}{l}\text { Nor } \\
\text { mal }\end{array}$ \\
\hline Systole post & 0.183 & $\begin{array}{c}> \\
0.05\end{array}$ & $\begin{array}{l}\text { Nor } \\
\text { mal }\end{array}$ & $\begin{array}{l}0.2 \\
73\end{array}$ & $\begin{array}{c}> \\
0.05\end{array}$ & $\begin{array}{l}\text { Nor } \\
\text { mal }\end{array}$ \\
\hline $\begin{array}{l}\text { difference } \\
\text { systole pre } \\
\text { and post }\end{array}$ & 0.389 & $\begin{array}{c}> \\
0.05\end{array}$ & $\begin{array}{l}\text { Nor } \\
\text { mal }\end{array}$ & $\begin{array}{c}0.0 \\
02\end{array}$ & $\begin{array}{c}> \\
0.05\end{array}$ & $\begin{array}{c}\text { Abno } \\
\text { rmal }\end{array}$ \\
\hline Diastole pre & 0.122 & $\begin{array}{c}> \\
0.05\end{array}$ & $\begin{array}{l}\text { Nor } \\
\text { mal }\end{array}$ & $\begin{array}{c}0.1 \\
15 \\
\end{array}$ & $\begin{array}{c}> \\
0.05\end{array}$ & $\begin{array}{l}\text { Nor } \\
\text { mal }\end{array}$ \\
\hline Diastole post & 0.181 & $\begin{array}{c}> \\
0.05\end{array}$ & $\begin{array}{l}\text { Nor } \\
\text { mal }\end{array}$ & $\begin{array}{l}0.1 \\
20\end{array}$ & $\begin{array}{c}> \\
0.05\end{array}$ & $\begin{array}{l}\text { Nor } \\
\text { mal }\end{array}$ \\
\hline $\begin{array}{l}\text { difference } \\
\text { diastole pre } \\
\text { dan post }\end{array}$ & 0.302 & $\stackrel{>}{0.05}$ & $\begin{array}{l}\text { Nor } \\
\text { mal }\end{array}$ & $\begin{array}{c}0.0 \\
50\end{array}$ & $\begin{array}{c}> \\
0.05\end{array}$ & $\begin{array}{c}\text { Abno } \\
\text { rmal }\end{array}$ \\
\hline
\end{tabular}

Table normality test results showed that all the data has a significance value of $p=0.05$ which means all the normal distribution of data unless the data delta is systolic and diastolic. So that further testing using parametric and nonparametric statistics, namely:

\section{Paired Difference Test}

Variable Stress

Table 4

Descriptive calculation and testing of paired t-test in the control group

\begin{tabular}{ccccc}
\hline Data & Mean & $\mathbf{N}$ & $\begin{array}{c}\text { Std. } \\
\text { Deviation }\end{array}$ & Sig. \\
\cline { 1 - 4 } Stress pre & 64.33 & 15 & 19.93 & 0.095 \\
\cline { 1 - 3 } Stress post & 71.67 & 15 & 25.99 &
\end{tabular}


The calculations show a score of stress before the control group was 64.33 and after 71.67 at from these results, it can be seen an increase in stress in the control group. To ensure that the significant difference in stress scores performed paired t-test. The calculations, a significance level of $p=0095$. Significance value is greater than $p=0: 05$ to stress the difference before and after the control group was not significant.

\section{Table 5}

Descriptive calculation and testing of paired t-test in the experiment group.

\begin{tabular}{lcccc}
\hline Data & Mean & $\mathbf{N}$ & $\begin{array}{c}\text { Std. } \\
\text { Deviation }\end{array}$ & Sig. \\
\hline Stress pre & 61.47 & 15 & 12.29 & 0.000 \\
\hline Stress post & 46.87 & 15 & 4.60 & \\
\hline
\end{tabular}

The calculations show stress scores before the experiment group was 61.47 and after at 46.87 . From these results, it can be seen a decline in stress in the group treated with hypnotherapy. To ensure that the significant difference in stress scores performed paired t-test. The calculations, a significance level of $p=0.000$. The significance value smaller than $p=0: 05$ so that differences in the experiment group significant stress.

\section{Variable Blood Pressure}

To ensure that the blood pressure between the two groups then tested in pairs and two free samples. Blood pressure observed in the study is the pressure diastole and systole. Here are the results better test results in diastolic and systolic blood pressure:
Table 6

Descriptive calculation and testing of paired t-test

\begin{tabular}{|c|c|c|c|c|c|c|c|c|c|}
\hline \multicolumn{4}{|c|}{ Control Group } & \multicolumn{5}{|c|}{ Experiment group } & \multirow[b]{2}{*}{$\begin{array}{c}\text { Sig } \\
\text { • }\end{array}$} \\
\hline Data & $\underset{\mathbf{n}}{\text { Mea }}$ & $\mathbf{N}$ & SD & $\begin{array}{l}\text { Si } \\
\text { g. }\end{array}$ & Data & $\underset{\mathbf{n}}{\text { Mea }}$ & $\mathbf{N}$ & SD & \\
\hline $\begin{array}{l}\text { Systo } \\
\text { le pre }\end{array}$ & $\begin{array}{c}152 . \\
00\end{array}$ & $\begin{array}{l}1 \\
5\end{array}$ & 8.62 & \multirow{2}{*}{$\begin{array}{l}0 . \\
2 \\
0 \\
7\end{array}$} & $\begin{array}{l}\text { Systo } \\
\text { le pre }\end{array}$ & $\begin{array}{c}152 . \\
00\end{array}$ & $\begin{array}{l}1 \\
5\end{array}$ & $\begin{array}{l}12 . \\
07\end{array}$ & \multirow{2}{*}{$\begin{array}{c}0.0 \\
00\end{array}$} \\
\hline $\begin{array}{l}\text { Sistol } \\
\text { e } \\
\text { post }\end{array}$ & $\begin{array}{c}155 . \\
33\end{array}$ & $\begin{array}{l}1 \\
5\end{array}$ & 11.25 & & $\begin{array}{l}\text { Systo } \\
\text { le } \\
\text { post }\end{array}$ & $\begin{array}{c}144 . \\
00\end{array}$ & $\begin{array}{l}1 \\
5\end{array}$ & $\begin{array}{c}9.8 \\
6\end{array}$ & \\
\hline $\begin{array}{l}\text { Diast } \\
\text { ole } \\
\text { pre }\end{array}$ & $\begin{array}{c}93.3 \\
3\end{array}$ & $\begin{array}{l}1 \\
5\end{array}$ & 6.17 & \multirow{2}{*}{$\begin{array}{c}0 . \\
5 \\
4 \\
6\end{array}$} & $\begin{array}{l}\text { Diast } \\
\text { ole } \\
\text { pre }\end{array}$ & $\begin{array}{c}91.3 \\
3\end{array}$ & $\begin{array}{l}1 \\
5\end{array}$ & $\begin{array}{c}9.1 \\
5\end{array}$ & \multirow{2}{*}{$\begin{array}{c}0.0 \\
01\end{array}$} \\
\hline $\begin{array}{l}\text { Diast } \\
\text { ole } \\
\text { post }\end{array}$ & $\begin{array}{c}92.0 \\
0\end{array}$ & $\begin{array}{l}1 \\
5\end{array}$ & 6.76 & & $\begin{array}{l}\text { Diast } \\
\text { ole } \\
\text { post }\end{array}$ & $\begin{array}{c}86.0 \\
0\end{array}$ & $\begin{array}{l}1 \\
5\end{array}$ & $\begin{array}{c}7.3 \\
7\end{array}$ & \\
\hline
\end{tabular}

The calculations show a score of systole before the control group was $152.00+8.62$ and after amounting to $155.33+11.25$. From these results, it appears that systole increases. The test results showed the level of significance $p$ $=0207(\mathrm{p}>0.05)$, so although systole increased the increase is not significant. Scores diastole before the control group was $93.33+6.17$ and the after of $92.00+6.76$. From these results, it appears that diastole decreased. The test results showed the level of significance $p=0.546(p>$ $0.05)$, so although diastole declined, but the decrease was not significant.

The calculations show systole score before the experiment group was $152.00+12: 07$ and after at $144.00+9.86$. From these results, it appears that systole decreased. The test results showed the level of significance $p=0.000(p<0.05)$, with a significant decrease in the experiment group significantly systole. Diastole score before the experiment group was $91.33+9.15$ and the after of $86.00+7: 37$. From these results, it appears that diastole decreased. The test results showed the level of significance $p$ $=0.001(\mathrm{p}<0.05)$, with this effect the diastole decreased significantly. 
Two different test Free Sample

Variable Stress

The next step is to test the difference between groups using data from the difference or delta. Here are the full results:

Table 7

Descriptive calculation and testing of paired t-test in the experiment group

\begin{tabular}{lcccc}
\hline \multicolumn{1}{c}{ Data } & N & Mean & $\begin{array}{c}\text { Std. } \\
\text { Deviation }\end{array}$ & Sig. \\
\hline $\begin{array}{l}\text { Delta control } \\
\text { group }\end{array}$ & 15 & -7.33 & 15.85 & \\
$\begin{array}{l}\text { Delta } \\
\text { experiment } \\
\text { group }\end{array}$ & 15 & & & 0.000 \\
\hline
\end{tabular}

The calculations show stress change in the control group -7.33, while the experiment group amounted to 14.60. From these results, it can be seen a decline in stress in the group treated with hypnotherapy with the average an average decrease of 14.6 while the control group increased. To ensure that the significant difference in stress scores performed two independent samples t-test. The calculations, a significance level of $p=0.000$. Significance value is smaller than $\mathrm{P}<0.05$ so that changes made before and after the stress of hypnotherapy in the control group and the experiment there are significant differences.
Variable Blood Pressure Control

Table 8 Testing test two independent samples in the control group and the experiment on blood pressure of elderly.

\begin{tabular}{|c|c|c|c|}
\hline Data & Group & $\begin{array}{l}\text { Mean } \\
\text { Rank }\end{array}$ & Sig. \\
\hline \multirow{2}{*}{$\begin{array}{c}\text { Difference } \\
\text { Systole }\end{array}$} & control & 20.80 & \multirow{2}{*}{0.000} \\
\hline & Experiment & 10.20 & \\
\hline \multirow{2}{*}{$\begin{array}{c}\text { Difference } \\
\text { Diastole }\end{array}$} & control & 17.43 & \multirow{2}{*}{0.188} \\
\hline & Experiment & 13.57 & \\
\hline
\end{tabular}

The calculations show changes in systolic blood pressure between control and experiment groups showed a mean difference of rank quite different. In the control group was 20.8, while in the experimental group 10.2. Mann Whitney test results obtained by the significant value of $p=0.000(p<0.05)$. From this result, there are significant differences between the systole blood pressure control and experiment groups and in other words, giving hypnotherapy can lower systolic blood pressure.

The calculations show changes in diastolic blood pressure among the control group at 17:43, while the experiment group at 13:57. Mann Whitney test results obtained by the significant value of $p=0188(p>0.05)$. From this result, there is a significant difference between the diastolic blood pressure control and experiment groups and in other words giving hypnotherapy can lower diastolic blood pressure is not real.

\section{DISCUSSION}

The research proves that there is the influence of hypnosis therapy against stress. The results of this study confirmed the results of 
calculation for paired t-test and independent $\mathrm{t}$ test. The results of this study became the basis that hypnosis therapy can be used as a method to reduce stress elderly. From the research results also show that not only stress that can be influenced by their hypnotic therapy. But also, blood pressure of elderly patients who were respondents of the study. Elderly are included in the experimental group experienced a reduction in blood pressure over the systole or significant. For diastolic blood pressure (the bottom blood pressure) also decreased, but the decrease was not significant.

Hypnotherapy can reduce stress and blood pressure is because basically, the concept of hypnosis therapy is to make the body relaxed, and then trained to think positive. The concept of Eastern medicine, the disease appears as a result of their self-denial or lack of selfacceptance will be something going on outside of ourselves. The rejection of conditions can cause stress. Stress is then made into the body's physiological changes. Hormones such as adrenaline released by the body without any control. With the hypnosis, the elderly are encouraged to think positively, accept. The psychological condition of the elderly will not taut.

The principle of hypnosis is performed using several stages of induction, deepening, suggestion and termination. How or communication techniques used to bring the subject into the hypnotic state is called induction. By induction, the subject made the conscious mind being busy, bored, or negligent in keeping the gates of the subconscious. Thus, the therapist can directly communicate with the subconscious mind of the subject. The induction phase is a suggestion that brings the normal elderly level to a stage hypnosis or elderly become very relaxed or asleep. Deepening phase is to guide subjects to imagine doing anything activities or is in a place that is easily felt so that it can enter a deeper trance level (Nurindra, 2006).

In the next process is done giving suggestion is a series of words or sentences delivered in a particular way, in certain situations, to give effect to those who listen consistently with the intent and purpose of this suggestion. Sentence suggestion in hypnosis using permissive sentences that ask and invite (not ruled), pacing and leading (using facts and advice), repetition (repetition) and language, words and phrases should be understood by the subjects. The final stage is termination of building positive suggestions that would make the body become more refreshed and relaxed, then followed by the matter of a few seconds to bring the subject to the normal conditions return. Stages subconscious become the central point of awareness is the main respondent level theta and delta. Theta is the brain waves, the frequency of 4-8 Hz range, which is generated by the subconscious mind (subconscious mind). The subconscious mind to save the human long-term memory and also the storehouse of creative inspiration. Moreover, the unconscious mind also stores the material that comes and creativity are pressed or not given the opportunity to come to the surface, and psychological material is pressed. Although humans can go into theta and access a variety of materials stored there, if not helped with alpha and beta waves, all of that material cannot be recognized by the conscious mind. All materials related to emotions, both positive and negative emotions, stored in the subconscious mind. Negative emotions are not rotated properly, after getting into the subconscious mind, eventually become a psychological burden that inhibits the progress of one's self. If man managed to get into the theta state will experience a very deep meditative state. All meditative experience that 
had been sought by people who practice meditation, for example, stillness, tranquility, depth, and the peak of happiness felt within theta. Theta is the "peak" in "peak experiences." When other wave components are in the right dosage, along with theta, humans can experience "ah-ha." When people want to treat and cure the body or mind, should go into theta order to achieve maximum results (Kusuma, 2002).

Delta is the slowest brain waves, the frequency range of $0.1-4 \mathrm{~Hz}$, and the frequency and (unconscious mind). When people sleep, the brain produces delta waves to rest and recover physical condition. In certain people, when in a conscious, delta exist with another wave. In that state, delta acts as a "radar" that underlies the work of intuition, empathy, and the action that is instinctive. Delta also provides policylevel very deep psychic awareness.

Their elderly hypnosis therapy can be trained to do a "meditation" with up to theta or delta phases that will make happiness effect and is expected to treat the problems of both body and mind. It is inevitable elderly age is a stage that allows them to have some of the tension that can cause stress. Stress can be related to family problems both children - children or grandchildren, economic problems and psychological problems that alienation to a psychological theory called the "empty nest" feeling less than helpful or useful to surroundings or feel alienated by the surrounding environment to experience the meaninglessness of life. Condition - This condition requires suggestion words - words so that the elderly become more relaxed in dealing with life.

This research was conducted in the elderly because the elderly person's physiological and pathological aging process will occur (aging process). According to Merry (2000), physiological aging occurs because it is influenced by endogenous factors, namely the change of the level of cells, tissues, and organs, then continues to the changes in the body system elderly. Structural and functional changes in peripheral blood vessels have an impact on blood pressure changes in the elderly. Changes that occur is the loss of elasticity of the connective tissue, atherosclerosis, decreased vascular smooth muscle relaxation which can lower the ability of blood vessels stretch resources. As a result, the ability to accommodate the aorta and arteries in the heart pumped blood volume decreases. Changes in blood volume decrease resulting in reduced cardiac output and increased peripheral resistance lead to high blood pressure (Black \& Hawks, 2001).

Many aspects of the physiological changes affected by pathological factors (secondary aging). Pathological factors more influenced by exogenous factors, such as environmental, social, cultural, and lifestyle. Ageing pathology can cause inability/disability in the elderly, as a result of trauma (Menz, Lord \& Fitzpatrick, 2003), chronic diseases (Matthews, Siemers \& Mozley, 2003), or degenerative changes arising due to the stress experienced by the individual (Kales ,Maixner\& Mellow, 2005). Stress can accelerate aging in a certain time, can further accelerate the process of degeneration occurs in the elderly when inflicting physical diseases (Lunney, Lynn, Foley, Lipson \&Guralnik, 2003). The pathological aging process that is the basis of hypnosis therapy. The inability or the stress experienced by the elderly is striving to overcome with their efforts to overcome the problems and effects unhappy or experiencing a peak experience in meditation at the time of entry in the level of theta waves. With the improvement in psychological functioning are 
expected to increase improvement in the physiological aspect because of basically many physiological diseases caused by psychological pressure.

This research was conducted in Elderly health care center, to do in Pacarkeling experiment group and the control group in Kemayoran. In the research process will not be successful if the respondent does not provide meaningful support. During the research process lasted cadre - cadre provides good support. So that citizen who were respondents also supported. Things strengthen the research process itself because of the respondents have a high curiosity that does not reject the existence of new knowledge about hypnotherapy. This condition is necessary, because in case of refusal then allow the failure of therapy done by researchers. The success of this therapy is also supported by the liveliness of the activities carried out in regular growth monitoring of elderly people so that they can share with other seniors and felt no other useful activities.

\section{CONCLUSIONS AND SUGGESTIONS}

\section{Conclusion}

Based on the research that has been done, the conclusion that can be drawn from this study is Hypnotherapy effect on stress reduction in the elderly. Decrease stress is also supported by the decrease in systolic blood pressure significantly although the decrease was not significant diastole. The ability of hypnosis in reducing stress because hypnosis is a nonpharmacological method that works at the level of human consciousness, especially at the level of the conscious and the subconscious which can cause a sensation in human beings happy.

\section{SUGGESTION}

Suggestions put forward from this study are: For the elderly should be the elderly with hypertension reduces stress by training themselves to do self-hypnosis at any time and continuously for hypnosis therapy safer, no side effects and cost. For the nursing profession should hypnosis therapy can be used as an alternative to nursing interventions for the elderly who have stressed that the death rate from hypertension can be reduced.

\section{REFERENCES}

Bolognesi, C.,et al. 1999 Chromosomal damage \& aging: effect on micronuclei frequency in peripheral blood lymphocytes. Age and aging, 28: 393-397.

Black.JM.,\& Hawk. JH. 2005. MedicalSurgical nursing clinical management for positive outcomes.(6th ed), Vol.2. St.Louis: Elsevier Saunders.

Gunawan. (2010). RahasiaIlmuHipnotis, www. adi gunawan.com, diperoleh 10 April 2011

Kusuma. 2002, Hipnosis untuk mengobati penyakit. www.http.republika.co.id, diperoleh 9 April 2011.

Kales, HC., Maixner, DF. \& Mellow AM. 2005. Cerebrovascular disease and late-life depression. AMJ GeriatryPsyciatry.February 13 (2): 88-89.

Lunney, JR.,Lynn, J., Foley, DJ., Lipson, S.\&Guralnik, ${ }^{\mathrm{i} J M}$. 2003. Patterns of functional decline at the end of life. JAMA May. 289 (18): 2387-2392.

Merry.BJ.2000. Notes on the biology of aging. Age and aging, 29:299-300.

Menz, HB.,Lord. SR., \&Fitzpatrick,RC. 2003. Age-related differences in walking 
stability. Age and aging, 32 (2): 137142

Matthews, B., Siemers, ER.,\&Mozley, PD.

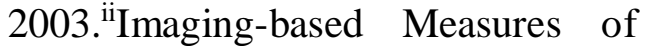
GeriatryPsyciatry. March-April 11 (2): $146-159$

Nurindra, Y. 2006. Pelatihan hipnoterapi tingkat mahir. Tidak dipublikasikan.

Penelitian, Erlangga University. Surabaya.
Sustrani.L.,Alam.S., Hadibroto.I. (2004). Hipertensi. PT. Gramedia. Jakarta. Zainudin (2000), Metodologdisease progression in clinical trials of disease-modifying drugs for Alzheimer disease. AMJ 